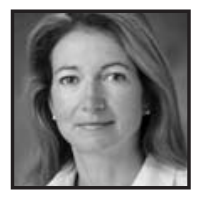

\title{
Weaving Tales and Leaving Trails
}

\author{
Georgia Heard
}

\section{ABSTRACT}

I have been thinking about the over-arching theme of the poems and I think that they are all about literacy in some form or another. "Straight Line" is about young children who are just entering into the world of words, and are taught in schools to be silent; "Stars" is about how we weave tales and songs from the night sky-and the world around us - to help us make meaning; and "The Paper Trail" is how ordinary words_-in our everyday lives leave trails—even after we are gone.

wrote this poem after watching my son's class return from recess one day. During this time when I visited primary-grade classrooms as a writing consultant it seemed that the environment had changed for young children. Schools were demanding straight lines in behavior and thought and as a result of No Child Left Behind and testing. This poem was symbolic of these strict environments.

\section{Straight Line}

All the kindergarteners

walk to recess and back

in a perfectly straight line

no words between them.

They must stifle their small voices,

their laughter, they must

stop the little skip in their walk,

they must not dance or hop

or run or exclaim. 
They must line up

at the water fountain

straight, and in perfect form,

like the brick wall behind them.

One of their own given the job

of informer - guard of quiet,

soldier of stillness.

If they talk

or make a sound

they will lose their stars.

Little soldiers marching to and from

pretend

their hair sweaty

from escaping dinosaurs

their hearts full of loving the world

and all they want to do

is shout it out

at the top of their lungs.

When they walk back to class

they must quietly

fold their pretends into pockets,

must dam the river of words,

ones they're just learning,

new words that hold the power

to light the skies, and if they don't

a star is taken away.

One star

by one star

until night grows dark and heavy

while they learn to think carefully

before skipping,

before making a wish.

"Straight Line" first appeared in A Place for Wonder: Reading and Writing Nonfiction in the Primary Grades (Stenhouse, 2009) by Georgia Heard and Jen McDonough. Reprinted with permission of the author. 
When I was about fourteen I would walk up to my grandfather's house and read to him from astronomy books. He had lost his eyesight and we would sit on the porch and I would read and he would fall asleep... I kept reading. He had a telescope on the porch, so every clear night I would look through it and I fell in love with the stars.

\section{Stars}

Connect the dots. Make sky stories:

Taurus the Bull; Aries the Ram;

Leo the Lion; the Big Dipper-

Tales stitched onto an endless night.

Find a star. Sing sky songs:

Twinkle, twinkle little star...

When you wish upon a star...

Melodies sung in a hushed night.

Originally published in Sky Magic, ed. Lee Bennett Hopkins, 2009.

Copyright by Georgia Heard. Reprinted with permission of the author.

This is a "found poem" that I gathered from snippets of newspaper articles after 9-11. I was living in New York City at the time and after 9-11 there was a snowstorm of paper floating all over the city and I thought of these paper snippets as the trails of people's unfinished lives.

\section{The Paper Trail}

They fluttered from the sky like a sweet and peaceful snowstorm: sheets and scraps - a crumpled page of cleaning instructions with a reminder to damp-wipe smudges and smears; a woman's cell phone bill; a hand-written note on paper decorated with kitchen herbs read: "...it would be nice to have another pot-luck dinner for parents"; a blank check numbered 3746 neatly torn from a check-book. 
Bits of paper floated into the open classroom windows, drifted into a second floor apartment window on Liberty Street. At St. Paul's Cathedral, in Lower Manhattan, three inches blanketed the old graves.

Originally published in A Kick in the Head, ed. Paul Janeczko, 2005.

Copyright Georgia Heard. Reprinted with permission of the author.

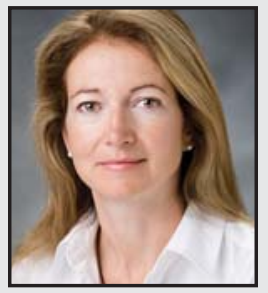

Georgia Heard received her M.F.A. in poetry from Columbia University. She is a founding member of the Teachers College Reading and Writing Project in New York City. Currently, she visits schools and speaks at conferences in the United States, Canada and around the world inspiring students and educators with her workshops and speeches. She is the author of numerous professional books on writing including Awakening the Heart: Exploring Poetry in Elementary and Middle School, which was cited by Instructor Magazine as "One of the Twelve Books Every Teacher Should Read." She is also the author of several books for children including her most recent Falling Down the Page: A Book of List Poems (Roaring Brook Press). 